\title{
VII
}

\section{THE ELIZABETHAN PERIOD POETRY AND PROSE}

\author{
[BY FREDRRICE S. BOAs]
}

Tus period since the Armistice has been too short for English scholars or publishers to resume their full activities. Hence the bulk of recent critical work on the Elizabethan period, whether in the form of books or of magazine articles, is of American origin. This is particularly true of the two great figures with which the period (as here defined) begins and closes-Spenser and Milton.

But one writer belonging to the homeland, Professor Jack, has in $A$ Conimentary on the Poetry of Chaucer and Spenser 1 'recast in more literary form' the Clark Lectures that he delivered in 1914-15 in Trinity College, Cambridge. His object throughout is 'to keep the poems constantly under review, not as documents in the history of literature, but as emotional compositions, which may or may not have retajned their power to please'. Of the seven chapters included in the volume four are devoted to Spenser. The two more important of these deal with his 'Poetry', and with 'Criticisms and Imitations' of his work. In speaking of the poems Professor Jack gives a running summary of them, interspersed with critical observations. All independent and thoughtful comment upon Spenser is to be welcomed, and many of the dicta on individual passages are illuminating and happily phrased. The appreciation of Book VI

1 A Commentary on the Poetry of Chawcer and Spenser, by Adolphus Alfred Jack, Chalmers Professor of English Literature in the Unirervity of Aberdeen. Glasgow: Maclehose, Jackson \& Co., 1920. ix + 369 pp. 8. 6d. net. 
of The Faeric Queene, 'a masterpioce fit to rank with the first three', is as warm as it is discriminating. But Professor Jack adopts a curiously magisterial attitude towards much of Spenser's work, especially in the minor poems. Thus of The Shepheardes Calendar he states that it 'is not undull to read through, but there are pretty things in it ... no longer a living performance'; and of Colin Chout's Come Home Again, 'if we say that structurally it is pleasurably discursive, we have exhausted judicious praise'. Even of The Faerie Queene he writes, 'mercifully this gigantic work was never finished'. The value of an interesting and often subtle piece of critical writing is impaired by an inadequate recognition of Spenser, whatever may be his defecte, as one of the dii maiores of Engliah poetry, whose work forms a great whole, to be handled with frankness but with reverence.

At the opposite extreme to Professor Jack's attitude is that of an American scholar, Mr. H. E. Cory, whose Edmund Spenser, $A$ Critical Study, ${ }^{2}$ published during the war, has recently become available in this country. Mr. Cory's enthusiasm for Spenser scarcely stops on this side of idolatry, and he writes in a flamboyant and diffuse style. He spins out his volume with lengthy quotations from the poet himself and from his critics, though it is fair to say that he states in his preface that his book is 'empirical in the sense that it is an attempt to come to certain conclusions about Spenser only on the basis of a vast number of experiences of other readers of Spenser in every decade from 1579 to 1917'. His chief object seems to be to maintain against 'romanticiats' on the one hand and 'realists' on the other that Spenser is both Teacher and Poet. The view, if it could have been stated with more restraint than by Mr. Cory, is in itself sound. And as his volume, though it has no index, is in some sort a compendium of all previous Spenserian criticiem, it is not without its use.

In $A$ Subject-Index to the Poems of Edmund Spenser, ${ }^{3}$ Profeseor

2 Edmund Spenser, a Critical Study, by H. E. Cory, University of California Press: Berkeley, 1917. 478 pp. \$2.50c.

I A Subject-Index to the Poems of Edmund Spenser, by Charles Huntington 
Whitman has provided Elizabethan students with a useful and well-printed manual. The author states that the title 'fails to give a wholly adequate idea of the work. It is an index in so far as it includes the names of persons, places, animals, and things, whatever, in fact, has a function and definite meaningwhatever in the compiler's judgment would be likely to prove of interest to the student of Spenser and his age. It partakes also of the nature of a dictionary, in that it includes brief explanations, allegorical and otherwise, whenever such explanations seem necessary'. As the Index is alphabetical the items are curiously mixed, and seem occasionally (as the work is not a concordance) to be unnecessary, e.g. 'Acres', merely because the word occurs incidentally in Faerie Queene, 1. xii. 11. Some of the crose-references are cumbrous and to little or no purpose. Thus under 'Ant', which occurs once in Visions of the Worlds Fanity, we are referred to 'Insects', and under 'Antelope', found once in Faerie Queene, r. vi. 26, to 'Mammals'. Spenser was after all a poet, not a zoologist. Some of the 'brief explanstions' of allusions are too summary to be really helpful. Thus 'Aetion', in Colin Cloul's Come Home Again (1.464), is set down as 'typifying Michael Drayton', without reason adduced or any indication of alternative interpretations. In the same poem 'Palaemon' (1. 396) is identified with Thomas Churchyard, and 'Palin' (1. 392) doubtfully with Thomas Challoner, but in neither cass is any proof assigned. Yet in spite of such deficiencies Professor Whitman's work is really helpful. It is a boon to be able to turn up at once the reference to any person or place mentioned in Spenser's poetry, especially in cases where the same name is used in two or more applications. Probsbly few persons could remember off-hand that 'Ouse' is the name of three different rivers in Faerie Queene, rv. xi, and that there is also an Irish river 'Oure'. And it is convenient to be able at a moment's notice to track Arthur or Duessa or Britomart in any part of the epic where they appear.

Whitman, Professor of English in Ratgers College. Published under the anspices of the Connecticnt Academy of Arts and Sciences. New Haven: Yale University Press. London: Humphrey Milford, Oxford University Press, 1918. $11+261$ pp. 15s. net. 
Spenser continues to occupy a prominent place in American learned periodicals. In Spenser and Utopia (Studies in Philology, The University of North Carolina, April 1920) Mr. Merritt Y. Hughes discusses the episode in the Faerie Queene, v. ii. 29-54, between Artegall and the communistic Giant. He suggests that the historical inspiration of the scene may not only have been the rebellion of the Anabaptists in Munster, but Ket's revolt in Norfolk in 1549.

In the Genesis of Spenser's Queene of Facrie (Modern Philology, May 1920), Professor C. R. Baskerville seeks to show that 'Spenser's selection of the figure of a fairy queen to symbolise the glory pursued by the knights and humanists of the Renaissance' was partly influenced by the entertainment given by Leicester to Elizabeth at Kenilworth in 1575, 'but more significantly by the complementary entertainment at Woodstock in the ane year'. He gives the details of the two entertainments that bear on the matter.

In Spenser's Initations from Ariosto: Supplementary (Publications of Modern Language Association of A merica, June 19191, Dr. A. H. Gilbert adds to the parallels noted by Professor Neil Dodge in the same Publications, 1897; and Professor Neil Dadge himeelf further supplements them in March 1920. In Spenser's Linguistics in 'The Present State of Ireland' (Modern Philology, December 1919), Dr. J. W. Draper, after an examination of the vocabulary in the pamphlet, comes to the conclusion that 'of the legal terms, English and Irish, Spenser seems to know the meanings; but his etymologies appear to be the merest guest-work and fancy. His Welsh etymologies of family names and of common nouns are, most of them, obviously and radically wrong. But . . The Present State of Ireland shows some knowledge of Irish common nouns; and Spenser's blunders point to his having supplied this knowledge himself rather than having called in expert assistance.'

The chief contribution made recently to the study of Milton comes from France. Dr. Denis Saurat's La Pensee de Milton *

- Ia Pensie de Milion, by Denis Sanrat, Docteur ès Lettres. Paris: Librairie Félix Alcan, 1920. 352 pp. $20 \mathrm{fr}$. 
is worthy to take its place beside the other notable monographs on Engliah poets that we have orred in late years to our allies across the Channel. It endeavours to set forth 'ce qu'il y a d'humain et de durable' in Milton's thought, and to show 'l'homogénéité de tout Milton, l'unité de l'homme même, dans les actes de sa vie privée et politique, et du penseur, et du poète'. The work is thus not a study of Milton's literary art, but of the ideas and principles which form the basis alike of his private and political actions, of his poems and his prose tracts. Dr. Saurat divides his treatise into thre Parta, of which the first is entitled 'La Formation'. Here he shows how the events of Milton's private and public life, the emotional catastrophe due to Mary Powell, and the shocks given to his ideals of liberty by Presbyterian formalism and Restoration licence, not only gave birth to the divorce tracts and the controversial pamphlets, but determined the poet's conception of the Fall of Man and the nature of Evil. He saw around him in the home and the State the triumph of passion over reason. How in such a world could he 'justify the ways of God to man'?

Milton's answer to the problem-an answer of faith-is dealt with by Dr. Saurat in the second Part of his volume, 'Lo Systeme', in which he analyse the poet's metaphysical, psyohological, and religious principles. These find their systematic and abstract expression in the Latin treatise De Doctrina Christiana, which was not published till 1825 ; and their poetic interpretation in Paradise Lost, Paradise Regained, and Samson Agonistes. Dr. Saurat's statement of the relation between the fundamental ideas in the treatise and in the poems, and of their value for morlern thought, may be reckoned the most important section of his work. In its third Part, 'L'Expression', he traces the scriptural and patriotic sources of Milton's epic narrative, giving prominence to the Book of Enoch and St. Augustine's De Civitate Dei; and he finally examines the three great poems in the light of the conclusions reached throughout his volume.

Dr. Saurat's style is lucid and attractive, but his reasoning is so closely knit that it is difficult to do justice to the book in a short summary. It should be read by every student of Milton, whether all the views set forth in it be accepted or not. It may 
be added that the writer is fully posted up in English criticism on Milton, from Thomas Newton to Mr. John Bailey.

A useful supplement to Dr. Saurat's volume is to be found in the two articles on Milton on the Position of Women (The Modern Langrage Revieto, January and July 1920), by Dr A. H. Gilbert, of Cornell University. So far as their special theme is concerned they follow (of course independently) much the same lines as the French monograph. They illustrate the similarity of Milton's views of the relation of the sexes in the Divorce tracts and in the poems, and lay stress on the fact, which is often not realized, that he asks for the woman the same right of divorce as for the man. Dr. Gilbert, like Dr. Saurat, realizes fully that ' the mental compenionship of husband and wife is for the poet the cornerstone of marriage', and declares truly that this principle 'has in it the spirit of life, and is capable of growth'. He therefore claims that though Milton insista that the man is the head of the woman, he is 'one of the world's teachers of a larger life for women, and indeed of liberty for all mankind'.

Another contribution of a very different kind by Dr. Gilbert to the study of the poet is A Geographical Dictionary of Milton, ${ }^{5}$ in which he gives in alphabetical order the place-names in Milton's prose and poetry. In explaining them he tries 'to reveal something of what they meant to the poet himself' by drawing the quotations, so far as possible, from books that he actually read. The principal source thus used is Purchas's Pilgrimes, from which extracts of considerable length are given. Some of the familiar quotations, in translation, from classical writers soem unnecessary, and crose-references are unduly multiplied. But the Dictionary is the fruit of scholarly zeal.

Dr. Gilbert in Milton and the Mysteries (Studies in Philology, April 1920) further suggests certain resemblances between paseages in the Ludus Coventriae, the Chester Plays, and the York

- A Geographical Dictionary of Mizton, by Allen H. Gilbert, Ph.D., Instractor in Engligh in Cornell Univeraity. New Haven : Yale University Press. London : Humphrey Milford, Oxford University Press, 1919. viii +922 pp. 
Plays, and episodes in Paradise Lost and Paradise Regained, though he adds that he does 'not intend to imply that these particular mysteries are certainly among the sources of Milton's two poems'. This is one of the numerous articles on various aspects of Milton's work which have appeared in the University of North Carolina Studies in Philology. Attention may be specially drawn to the issue of July 1920, which is devoted entirely to the poet. Mr. Alwin Thaler, in Milton in the Theatre, gives remarkable details of the adaptations of Paradise Last and other of the poems for dramatic or musical purposes, and of the stage career of Comus at Covent Garden, Drury Lane, and elsewhere from 1738 to 1843 . Mr. J. H. Harford in The Date of Milton's De Doctrina Christiana gives grounds for the view that the treatise was completed not much later than 1680. Mr. Edwin Greonlaw in Spenser's Influence on 'Paradise Lost', argues that the evidence 'for Dryden's statement that Milton acknowledged Spenser to be his original' is to be found in the Foure Hymnes and in the cantos of Mutabilitie'.

In the Publications of the Modern Language Association of America short articles worth attention will be found on The Editions of Milton's History of Britain (March 1920) by Mr. H. Glicksman, and on Milton and Plato's Timaers (June 1920) by Mr. E. C. Baldwin. The latter also writes on Milton and the Psalms in Modern Philology (December 1919). From the poet's translation of seventeen Psalms he infers that 'his acquaintance with Hebrew was a literary rather than a linguistic or scholarly one', and 'did not furnish an adequate equipment for the task he set before himself'. The same publication contains two carefully worked out articles (September 1919 and January 1920) by Mr. George Sherburn on The Early Popelarity of Milton's Minor Poems.

When we turn to the work of individual poets of lower rank than Spenser or Milton, the most important piece of recent research is Dr. Lyon's A Study of 'The Neve Metamorphosis'. ${ }^{\circ}$

- A Study of 'The Newo Metamorphosis', written by J. M. Gent, 1600, by John Henry Hobart Lyon, Ph.D., Litt.D. New York: Columbir Dniverrity Press, 1919. London: Humphrey Milford, Oxford Univeraity Press. $36+220$ pp. 8s. $6 d$. 
The manuscript of The Newe Hetamorphasis is contained in three volumes in the British Museum (MSS. Addit. 14824-6). It consists of 884 pages, with over thirty thoukand rhymed heroic couplets, and is divided into 'Tomus primus' and 'secundus', each subdivided into twelve Books. There are two title-peges, each bearing the date 1600 , but as there are allusione in the text to the death of Henry, Prince of Wales, and the marriage of the Princess Elizabeth, as well as to books published in 1613 or later, the work cannot have been completed before 1614 or 1615 .

Though The Newe Metamorphosis has attracted the attention of scholars, from F. G. Waldron (who once owned the MS.) and Joseph Haslewood onwards, Dr. Lyon has been the first to examine it thoroughly, and to show its width of range and variety of interest. It is 'essentially a collection of stories, the majority of them of evildoers who by some metamorphosis are punished by the wronged gods. It is a continuation in verse of the popular work of Painter, Fenton, Pettie, Rich, and their imitators, except that Ovid and contemporary life often furnished the colouring and motif'. Besides being a story-taller in verse the author is also a satirist, who inveighs against the vices and follies of the day, and fiercely denounces Roman Catholicism. Furthermore, in his account, as an eyewitnese, of the expedition of the Earl of Essex to Cadiz, of his own experiences in Ireland, and of the Gunpowder Plot, he supplies valuable foot-notes to history.

Besides setting forth and illustrating with extracts the various aspects of The Nero MIetamorphrasis, Dr. Lyon discusses at length the question of its authorship. He proves conclusively (in the present writer's opinion) that the identification of $J$. M. with John Marston has no basis, and he makes out a strong case for Jervase (Gervase) Markham. The last word on this question has probably not yet been said, but in any case Dr. Lyon has made one of the most valuable contributions of present-day American scholarship to Elizabethan research.

Another question of identification is discussed by Miss $\mathbf{M}$. St. Clare Byrne in her article The Shepherd Tony-A Recapitulation (Modern Langrage Assaciation, October 1920). Comparing the poems attributed to the 'Shepherd Tony' in England's 
Helicon with $A$. Banquet of Dainty Conceits and other acknowledged verses by Anthony Munday, she concludes ' that there are no valid reasons for discrediting Munday's claim on grounds of style, but that there are, on the contrary, definite points of resemblance between his acknowledged work and the Shepherd Tony poems'. With regard to 'positive facts to confirm the theory of their identity', Miss Byrne recognizes that an unexpected difficulty has arisen. One of the Shepherd Tony poems, 'I serve a Mistress whiter than the snow ', forms ll. 224-41 of the play Fedele and Fortunio, which, according to J. P. Collier, contained a dedication to John Heardson by A. M., i.e. Anthony Munday. But, as the present writer pointed out, ${ }^{7}$ the copy of Fedele and Fortunio which was in the Mostyn collection has a dedication to M. R. and is signed not A. M. but M. A. Mise Byrne suggests that M. A. may be a transposition of Munday's initials, and adduces various arguments in favour of his authorship. Mr. W. J. Lawrence takes a somewhat similar line in The Authorship of 'Fedele and Fortunio' (Times Literary Supplement, 20 May, 1920) in which he goes more fully into Munday's early association with the stage. ${ }^{8}$

Mr. Hyder E. Rollins, in William Elderton: Elisabethan Actor and Ballad-Writer (Studies in Plilology, April 1920), gives a more coherent account of Elderton's career than has hitherto been attempted, and throws interesting sidelights upon the historical and social events which were the occasion of his fugitive but highly popular compositions.

In Charles Fitsgeffrey, Poet and Divine (Modern Lanouage Review, July 1919), Professor Moore Smith has thrown fresh light on the West Country Oxonian, who was author of a pootical eulogy in English of Sir Francis Drake (1585), and of

7 'The Mostyn Plays', The Times Literary Supplement, 20 Febroary, 1919.

- Since the above was written Dr. W. W. Greg has announced (The Times Literary Supplement, 12 May, 1921) that the copy eeen by Collier has been found in the library of Mr. Henry E. Huntington. The discrepancy between the initials in the two copies still presents a problem. The Mostyn copy has also the initials M. A. after the Epilogue. In the copy seen by Collier the page containing the Epilogne in missing. 
Affaniae (1601), a collection of Latin epigrams and funeral poems. The number of notable contemporaries commemorated in Affaniae gives it considerable value for biographical purposes.

A more eminent post and divine is the subjoct of Mies Willett's Traherne. ${ }^{9}$ The main thesis of this well-written essay is that 'Traherne's true medium was prose, not verse ... Metre and rhyme did not help his genius, but hampered it'. Hence Miss Willett, after a general consideration of Traherne's place among contomporary mystics, deals mainly with his Christian Ethics and Centuries of Meditation. It is on the latter work especially that in her opinion ' $h i s$ claim to immortality rests'. She gives an analysis of its leading ideas, and shows its biographical value. She illustrates her view of the superiority of his best prose to his best verse by quoting side by side Traherne's account of the 'pure and virgin apprehensions of infancy' in his poem Wonder and the parallel passages in The Centuries of Meditation.

A selection of the prose of Thaherne's greatest predecessor has been made available by Mr. Pearaall Smith in Donne's Sermons. ${ }^{10}$ The editor in his 'Introduction' explains the neglect of Donne as a prose writer. 'His shorter prose pieces ... do not represent him at his best; it is only here and there in 81 isolated passages of his sermons that he put forth his full strength ; and his best prose not being therefore easily accessible, has almost entirely escaped notice.' Mr. Pearsall Smith (like Miss Willett in the case of Traherne) claims that Donne's ' mastery of the means of expression was perhape even greater in prose than in poetry ; was less impeded by those defects of technique and temperament which kept him from reaching the highest level of poetic achievement'.

The volume includes 155 extracts from the 160 sermons of Donne, the punctuation and spelling of the original text in the folios or quartos being retained. The extracts are arranged in

- Traherne an Easay, by Gladys E. Willett. Cambridge: W. Heffer \& Sone, 1919.57 pp. 2s. 6d. net.

" Donne's Somors. Seleoted Pasarges with an Earay by Loogan Pearaall 8mith. Oxford: at the Clarendon Press, 1920. lii +262 pp. 6s. net. 
sequence according to their subjects. First come autobiographical passages : and then, in order, allusions to contemporary events ; passages illustrating the more secular aspects of Donne's thought; passages concerned with religious faith and its revelation, and those in which the body of that revelation is expressed. In his choice and arrangement of these extracts, and by his illuminating Introduction and useful notes, $\mathbf{M r}$. Pearsall Smith has done valuable service to Donne's reputation as a writer of prose and a theologian.

In The Mystical Poets of the English Church ${ }^{11}$ Mr. Osmond takes a wide sweep ranging from the thirteenth-century Franciscan, Thomas Hales, and Richard Rolle of Hampole, to contemporary writers like Mr. A. S. Cripps and Miss Evelyn Underhill. The book is popular in its aim, and the author states that it ' is little more than an Anthology compiled from the mystical poets of the English Church, with briefer extracts from some outside that Communion'. But it is agreesbly written, and goes outride the beaten track of the subject. In the period with which we are here concerned, Mr. Osmond deals not only with the greater figures but with Christopher Harvey, author of The Symagague (1640) and Schola Cordis (1647); and the Philadelphian, Samuel Poradge, who publiahed in 1661 Mun dorum Explicatio, an attempt to popularize in poetic form part of the theosophy of Boehme. ${ }^{12}$

Terser and more penetrating is Mr. H. J. Massingham's analysis of the characteristics of the mystical poetry of the ' metaphysicals' in his Introduction to A Treasury of Seventeenth Century English Verse. ${ }^{13}$ Here the editor has collected about four hundred poems from publications between 1616 and 1660 .

"The Mystical Poets of the English Church, by Percy H. Omond. London : Society for Promoting Christian Knorledge. New York: The Macmillan Co., 1919. xi +436 pp.

18 In Studies in Philology (April 1820) in The Lyrical Conceits of the Metaphysical Poets, Prof. R. M. Alden classifies these conceits as 'Imnginative' and 'Logical', with various subdivinions.

is $A$ Trearury of Secentoenth Century English Vorse. From the Death of Shakespeare to the Restoration (1616-1660). Chosen and edited by H.J. Massingham. London : Macmillan \& Co., 1919. 23+B99 pp. 3s. 6d. net. 
To make room for less familiar matter, he has left out Herrick and Milton altogether and the best-known poems of their chief contemporaries. He computes that more than a fourth of his selections 'are entirely new to the modern anthology', while 'a large number of the rest have appeared either in expensive, out of print, old, special or otherwise not easily accessible collections'.

Mr. Massingham has done a praiseworthy work in making accessible in the convenient 'Golden Treasury' form 80 many poems from Miscellanies, Drolleries, Plays, and other sources out of the ken of the general reader. And his copious notes, though sometimes arbitrary or prejudiced, contain much acute and sprightly criticism. The defects of his work have been shown by Professor Grierson in an excellent review of it (Modern Language Review, July 1920), where he illustrates the editor's practice of cutting and carving the poems at will, and the textual errors which he has admitted into them. There are also some wrong ascriptions.

It is highly interesting to compare the psychological treatment of love and other emotions in Mr. Massingham's Treasury with the simple and spontaneous strains of the preceding quarter of a century gathered by Mr. E. H. Fellowes in English Madrigal Verse. ${ }^{14}$ Mr. Fellowes has collected from a souroe hitherto only partially tapped-the Elizabethan song-books-a large number of delightful lyrics, very many of them anonymous. He has arranged them into two Parts, according as they are taken from the song-books of the madrigal composers proper or of the lutenists. The madrigal was seldom to more than one stanza of poetry, and the music was printed in separate part books, each of these books containing the music for one voico-part alone, with often slight variations in the verbal phrases. Hence, as Mr. Fellowes shows, the work of metrical reconstruction in some cases, when the poem is not otherwise known, is to some extent speculative. The words to which the airs of the lutenists are set present no such difficulty. They

14 English Madrigal Vors, 1588-1681. Edited from the Original Song Books by E. H. Fellowes. Oxford : at the Clarendon Press, 1920. II + 610 pp. 12s. 6d. net, and (India paper) 15s. net. 
consist usually of several stanzas, the first being set up with the mukic in the song-books, while the subsequent stanzas are printed in metrical form on another part of the page. Mr. Fellowes gives the words from the song-books of twenty-five madrigalists and twenty-one lutenists, and adds instructive notes. It would have been useful if in addition to the index of first lines, with their source in the song-books, an inder of authors (where known) had been given. Yet the charm of the collection lies in the fact that dozens of lyrics by unknown singers have here the same enchantment as the sweetest strains quoted from Spenser or Sidney.

An account has been given in the chapter on 'Literary Criticism and History' 15 of a scholarly investigation into the formal aspect of part of the poetry of this period which has been made by an alumnus of Princeton, Dr. Robert Shafer, in The English Ode to 1660.

Though the attention of editors and critics has been concentrated mainly on Elizabethan poetry, two important prose works have been reiesued, the one in part, the other complete. Professor K. N. Colville has printed selections (in modernized spelling) from Sir Thomas North's The Diall of Princes, ${ }^{16}$ the version, at second hand, of Guevara's Libro del Emperador Marco A urelio co Relox de principes. The volume which is the first issue of a new eries 'The Scholar's Library', contains about one-tenth of the text of The Diall, but the Table of Contents of the original quarto is prefixed to the selections. These include inter alia the dialogue of the Emperor and his wife about the key of his study; the villain of the Danube; and manners for courtiers from Book IV, which is a translation not of Guevara's Relox de principes but of his Aviso de Privados. The editor in his Introduction seeks, in opposition to Landmann, to minimize the debt of Euphues to Guevara. But there are coincidences

1s Soe above, p. 13.

1 The Diall of Princes, by Don Anthony of Guevara. Translated by Sir Thomes North. Being eelect passagee now set forth with an Introdaction and a Bibliography by K. N. Colville. London: Philip Allan \& Co., 1919. xlviii +263 pp. 10s. 6d. net. 
between Lyly's novel and the Diall which cannot be due to chance, and Professor Colville's selections illustrate North's occasional use of 'parisonic antithesis' which Lyly made into a system.

Mr. Brett-Smith's edition of The Unfortunate Traveller ${ }^{17}$ is the first issue of another series for students, The Percy Reprints. Neshe's novel is here reproduced from the second edition, of which the only known perfect copy is in the Bodleian. The original spelling and punctuation are preserved, but some readings from the first edition are admitted, where they are clearly the better. There is an interesting Introduction, making more of the work as a historical than a picturesque novel, and some notes in explanation of obsolete words and phrases.

17 The Unfortunate Traveller, or The Life of Jacke Willon, by Thomse Nashe. Edited by H. F. B. Bratt-Smith. Oxford: Basil Blackwell. IV +132 pp. 5s. net. 